\title{
Release Pattern of Inorganic N, Phosphorus and Potassium as Influenced by Farmyard Manure and Pressmud Compost under Laboratory Incubation Study
}

\author{
Bipin Bihari, Ragini Kumari* and Shweta Shambhavi
}

Department of Soil Science \& Agricultural Chemistry, Bihar Agricultural University, Sabour, Bhagalpur (813210), India

*Corresponding author

\section{A B S T R A C T}

\section{Keywords \\ Farmyard manure, Pressmud compost, Incubation, Ammonical- $\mathrm{N}$, Nitrate-N, available Phosphorus and available Potassium \\ Article Info \\ Accepted: \\ 18 August 2018 \\ Available Online: \\ 10 September 2018}

\begin{abstract}
Knowledge of the nutrient release from organic residues helps in optimizing nutrient effciency in agricultural crop production systems. A laboratory incubation experiment was conducted in Completely Randomized Design to assess the release of Ammonical-N, Nitrate-N, available Phosphorus and Potassium in soil incubated with two organic sources viz. farmyard manure and pressmud compost $\left(\mathrm{T}_{0}=\right.$ Control, $\mathrm{T}_{1}=5$ MT ha ${ }^{-1}$ organic manure, $\mathrm{T}_{2}=10 \mathrm{MT}_{\mathrm{Ma}}{ }^{-1}$ organic manure, $\mathrm{T}_{3}=15 \mathrm{MT}^{-1}$ organic manure, $\mathrm{T}_{4}=20 \mathrm{MT} \mathrm{ha}^{-1}$ organic manure) at different days $(0,30,60,90,120)$ after incubation under controlled aerobic condition. The study revealed that $\mathrm{NH}_{4}-\mathrm{N}$ content showed decreasing while $\mathrm{NO}_{3}-\mathrm{N}$ showed increasing trends whereas available phosphorus and potassium content increased from 0 to $30 \mathrm{DAI}$ and then decreased gradually up to $120 \mathrm{DAI}$.
\end{abstract}

\section{Introduction}

Maintenance of adequate levels of soil nutrients plays a key role in sustaining crop yield. Laboratory incubations are valuable and widely used tools for studying organic manure decomposition in soils which play a vital role in maintaining soil fertility.

Incubation of organic residue with soil has been used to study nutrient release from farmyard manure and pressmud compost at different days after incubation, which act as key for availability of nutrient at different period of time during crop growth. The nutrient release of an organic residue depends on its chemical and biochemical characteristics (Tian et al., 1992, 1995), referred to as its quality. Residue quality and environmental conditions regulate the rate and the extent of decomposition of organic matter by soil organisms (Moorhead et al., 1996). Study of nutrient release pattern from organic manures is very essential to ensure nutrient supply in adequate quantity and at proper time to crop plants. Organic matter plays a prominent role in increasing the level of soil fertility and sustaining the productivity of soils as well as the nutrients released from organic residues helps in optimizing nutrient 
efficiency in agricultural crop production systems. Knowledge of the nutrients released from organic residues will enables management systems to be devised that utilize these organic residues more effectively (Villegas-Pangga et al., 2000).

\section{Materials and Methods}

An incubation study has been conducted at Department of Soil Science \& Agricultural Chemistry for determining the nutrients release of Nitrogen (ammonical-N and nitrate$\mathrm{N}$ ), available Phosphorus and Potassium from two different organic manures viz. FYM and Pressmud compost. The bulk soil (Typic Haplustepts) samples used for the incubation study had been collected from the field experimental site prior to sowing of the crop. It was air dried, finely ground and sieved with $2 \mathrm{~mm}$ sieve for incubation studies having initial nutrients status viz. mineralizable $\mathrm{N}$ 162.6, $\mathrm{P}_{2} \mathrm{O}_{5}-43.1$ and $\mathrm{K}_{2} \mathrm{O}-167.2 \mathrm{Kg} \mathrm{ha}^{-1}$. The water holding capacity of soil was determined by Keen's cup method given by Keen-Razkowski (1921). In incubation studies duplicate of $30 \mathrm{gm}$ soil samples were taken in plastic bottles and were mixed with graded doses of farmyard manure and pressmud in Completely Randomized Design. Distilled water was added to maintain the moisture at field capacity (60 per cent of the water holding capacity). The samples were incubated at $25^{\circ} \mathrm{C}$ and sampling for analysis of $\mathrm{NH}_{4} \mathrm{~N}$, $\mathrm{NO}_{3}-\mathrm{N}$, phosphorus and potassium of soil was done at $0,30,60,90$, and 120 days after incubation. The $\mathrm{NH}_{4}-\mathrm{N}$ and $\mathrm{NO}_{3}-\mathrm{N}$ form of nitrogen were determined immediately after taking out sample from incubator by the method illustrated by Kenny and Nelson in 1982 and rest of the soil were air dried and stored at room temperature and analyzed for phosphorus (Olsen et al., 1954) and potassium (Hanway and Heidel, 1952). Initial NPK content of farmyard manure, pressmud compost were determined by the methods as outlined by Jackson (1973). Initial nitrogen of soil was determined by alkaline potassium permanganate method (Subbiah and Asija, 1956), available phosphorus was determined by ammonium-molybdate-ascorbic acid method using Spectrophotometer as outlined by Olsen et al., 1954 and available potassium was determined by flame photometer after extracting the soil with neutral normal ammonium acetate, Hanway and Heidel (1952) (Table 1).

The data collected for all the characters involved under study was statistically analysed by Completely Randomized Design by the method of analysis outlined by Panse and Sukhatme (1967) for proper interpretation.

\section{Results and Discussion}

\section{Ammonical nitrogen and nitrate nitrogen content}

The amount of ammonical nitrogen in soil at different intervals of incubation of soil at 25 ${ }^{0} \mathrm{C}$ as influenced by levels and sources of organics (farmyard manure and pressmud compost) is depicted in Table 2. Results showed that the release of ammonical nitrogen was lowest in soil receiving no manure in comparison to treatment receiving farmyard manure and pressmud compost. There was decrease in ammonical nitrogen content throughout the incubation period. The decrease in the ammonical nitrogen concentration was due to nitrification and possibly immobilization and volatilization. Similar results were found by Duffera et al., (1999), Mohanty et al., (2010), Kolahchi et al., (2012).

Result presented in Table 3 showed that the release of nitrate nitrogen was lowest in soil receiving no manure in comparison to treatment receiving farmyard manure and pressmud compost. There was gradual 
increase in nitrate nitrogen from 0 to 90 days after incubation (DAI), and decreased thereafter up to 120 days of incubation. The treatment $\mathrm{T}_{4}$ recorded highest nitrate nitrogen and was significantly higher than all the treatments. Increase in nitrate nitrogen content in case of farmyard manure from 30 to 60 days and 60 to 90 days of incubation was about $3.34 \%$ and $0.90 \%$ respectively, whereas in case of pressmud it was to the extent of $3.28 \%$ and $3.87 \%$ respectively. Results suggest that inclusion of organic material maintains considerable amount of nitrate nitrogen for longer period of time and depletes at slower rate. Availability of nitrate nitrogen increases in organically amend mended soil due nitrification of ammonical nitrogen and mineralization of rapidly mineralizable organic nitrogen. Duffera et al., (1999) found that during incubation period, ammonical nitrogen concentration remained low, while nitrate nitrogen concentration increased exponentially. The low ammonical nitrogen concentration and increase in nitrate nitrogen concentration suggest that nitrification of ammonical nitrogen was proceeding faster than mineralization of organic nitrogen to ammonical nitrogen. Similar results were also reported by Mohanty et al., (2010), Kolahchi and Jalali (2012).

\section{Available phosphorus}

The results obtained with respect to the content of available $\mathrm{P}$ in soil treated with different levels and sources of organics have been presented in Figure 1 and 2. Results show that the release of phosphorus was lower in soil receiving no organics in comparison to treatment receiving farmyard manure and pressmud compost. There was increase in available phosphorus in soil from 0 to 30 days of incubation (DAI) and there after a gradual decrease up to 120 days of incubation. Results suggested that inclusion of organic material maintains considerable amount of available phosphorus for longer period of time and depletes at slower rate. In case of farmyard manure and pressmud compost the treatment $\mathrm{T}_{4}$ (20 MT ha ${ }^{-1}$ organics) recorded highest phosphorus content at $30 \mathrm{DAI}$ which was at par with the treatment $\mathrm{T}_{3}\left(15 \mathrm{MT} \mathrm{ha}^{-1}\right.$ organics). The increase in available $\mathrm{P}$ content in treatment $\mathrm{T}_{4}$ was $86 \%$ and $101 \%$ in farmyard manure and pressmud compost treated plots respectively over $\mathrm{T}_{0}$ (control) while, the decrease in content from 30 to 60 DAI was to the tune of $1.53 \%$ and $2.2 \%$ in case of farmyard manure and pressmud compost treated plots respectively. Availability of phosphorus increases in organically amended soils due to large reduction in $\mathrm{P}$ sorption. Phosphorus sorption decreased possibly due to competition between phosphate ion and organic compounds that is phenolic and carboxylic and heterocyclic compound, for $\mathrm{P}$ retention sites in soil. The added organic forms coating on sesquioxide that reduced phosphorus fixing capacity of soil and increase the availability of phosphorus, the observation was consistent with the finding of Kumar et al., (2015). After 30 days, there is decrease in available phosphorus because of liberation of organic bound phosphorus during organic matter decomposition and subsequent immobilization of excess mobilized phosphorus as reported by Singh and Patel (2016).

Table.1 Initial nutrient status of organic sources

\begin{tabular}{|l|c|c|c|}
\hline Materials & N & P & K \\
\hline Farmyard manure (\%) & 0.6 & 0.95 & 1.1 \\
\hline Pressmud (\%) & 1.8 & 2.1 & 1.2 \\
\hline
\end{tabular}


Table.2 Effect of graded doses of farmyard manure and pressmud compost on $\mathrm{NH}_{4}-\mathrm{N}$ content $\left(\mathrm{mg} \mathrm{kg}^{-1}\right)$ during incubation at different days

\begin{tabular}{|c|c|c|c|c|c|c|c|c|c|c|}
\hline Organic sources & \multicolumn{5}{|c|}{ Farmyard manure } & \multicolumn{5}{|c|}{ Pressmud compost } \\
\hline Treatments & 0 & 30 & 60 & 90 & 120 & 0 & 30 & 60 & 90 & 120 \\
\hline Control $\left(\mathrm{T}_{0}\right)$ & 50.39 & 40.74 & 35.60 & 32.80 & 31.00 & 51.99 & 42.58 & 34.21 & 31.90 & 31.20 \\
\hline $5 \mathrm{MT} \mathrm{ha}^{-1}\left(\mathrm{~T}_{1}\right)$ & 53.99 & 45.22 & 37.00 & 33.58 & 33.20 & 54.00 & 49.93 & 38.78 & 36.25 & 35.80 \\
\hline $10 \mathrm{MT} \mathrm{ha}^{-1}\left(\mathrm{~T}_{2}\right)$ & 57.59 & 48.70 & 39.00 & 36.25 & 36.10 & 57.60 & 52.68 & 41.47 & 38.50 & 38.27 \\
\hline $15 \mathrm{MT} \mathrm{ha}^{-1}\left(\mathrm{~T}_{3}\right)$ & 61.20 & 50.93 & 42.74 & 39.70 & 39.30 & 72.00 & 57.72 & 46.90 & 45.20 & 44.25 \\
\hline $20 \mathrm{MT} \mathrm{ha}^{-1}\left(\mathrm{~T}_{4}\right)$ & 65.00 & 57.72 & 48.00 & 45.50 & 44.90 & 75.00 & 64.51 & 53.78 & 49.80 & 49.65 \\
\hline $\operatorname{LSD}(p=0.05)$ & 4.31 & 3.69 & 3.64 & 6.15 & 4.75 & 5.44 & 4.64 & 5.17 & 2.65 & 2.94 \\
\hline S.Em & 1.19 & 1.01 & 1.00 & 1.69 & 1.31 & 1.50 & 1.28 & 1.42 & 0.73 & 0.81 \\
\hline
\end{tabular}

Table.3 Effect of graded doses of farmyard manure and pressmud compost on $\mathrm{NO}_{3}-\mathrm{N}$ content (mg kg-1) during incubation at different days

\begin{tabular}{|c|c|c|c|c|c|c|c|c|c|c|}
\hline Organic sources & \multicolumn{5}{|c|}{ Farmyard manure } & \multicolumn{5}{|c|}{ Pressmud compost } \\
\hline Treatments & 0 & 30 & 60 & 90 & 120 & 0 & 30 & 60 & 90 & 120 \\
\hline Control $\left(\mathrm{T}_{0}\right)$ & 45.26 & 58.63 & 53.72 & 51.31 & 51.00 & 48.57 & 60.00 & 54.63 & 51.71 & 51.50 \\
\hline 5 MT ha $^{-1}\left(\mathrm{~T}_{1}\right)$ & 47.31 & 68.86 & 71.69 & 72.57 & 72.00 & 51.43 & 73.73 & 74.74 & 76.00 & 74.30 \\
\hline $10 \mathrm{MT} \mathrm{ha}^{-1}\left(\mathrm{~T}_{2}\right)$ & 49.37 & 79.31 & 80.97 & 83.89 & 81.00 & 57.14 & 84.34 & 87.26 & 91.69 & 90.20 \\
\hline $15 \mathrm{MT} \mathrm{ha}^{-1}\left(\mathrm{~T}_{3}\right)$ & 55.54 & 86.29 & 92.57 & 94.29 & 90.00 & 65.71 & 96.00 & 98.97 & 103.14 & 101.00 \\
\hline $20 \mathrm{MT} \mathrm{ha}^{-1}\left(\mathrm{~T}_{4}\right)$ & 59.66 & 98.86 & 102.17 & 103.09 & 101.00 & 71.43 & 102.63 & 106.00 & 110.11 & 108.00 \\
\hline LSD $(p=0.05)$ & 4.65 & 5.43 & 5.44 & 3.66 & 3.64 & 5.49 & 5.74 & 6.90 & 7.80 & 7.30 \\
\hline S.Em & 1.28 & 1.49 & 1.50 & 1.01 & 1.00 & 1.51 & 1.58 & 1.90 & 2.14 & 2.01 \\
\hline
\end{tabular}


Fig.1 Effect of graded doses of farmyard manure on available phosphorus content during incubation at different days

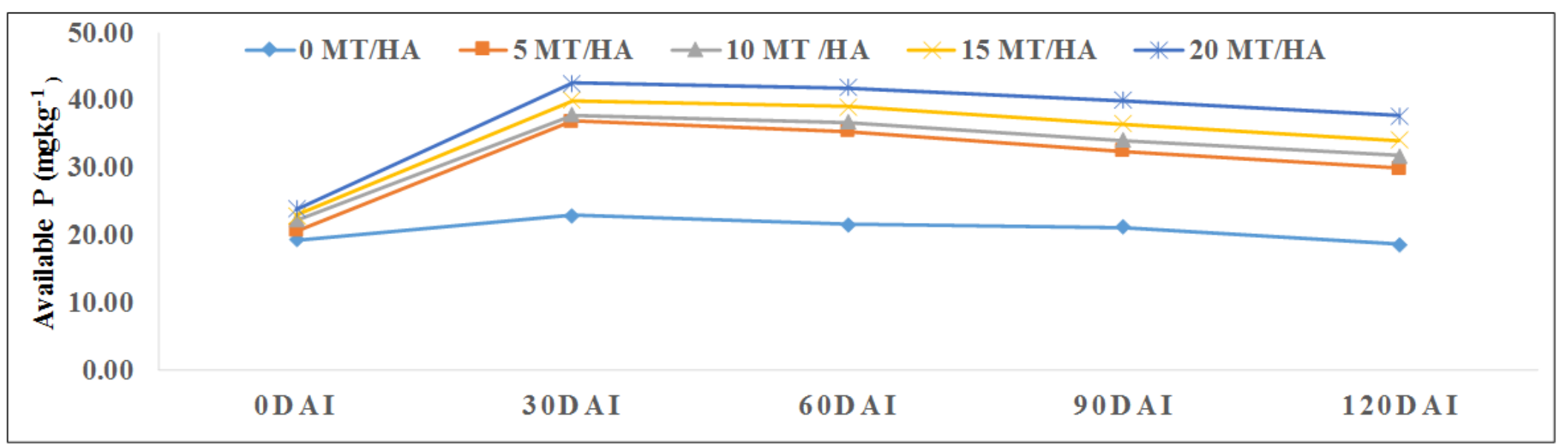

Fig.2 Effect of graded doses of pressmud compost on available phosphorus content during incubation at different days

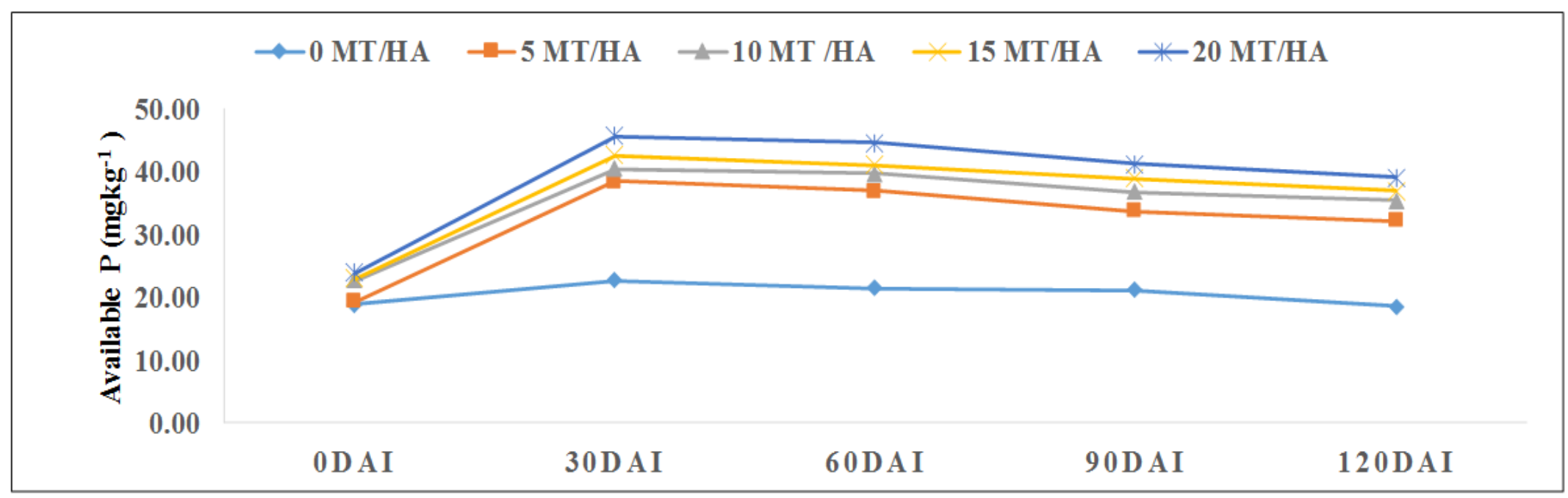


Fig.3 Effect of graded doses of farmyard manure on available potassium content during incubation at different days

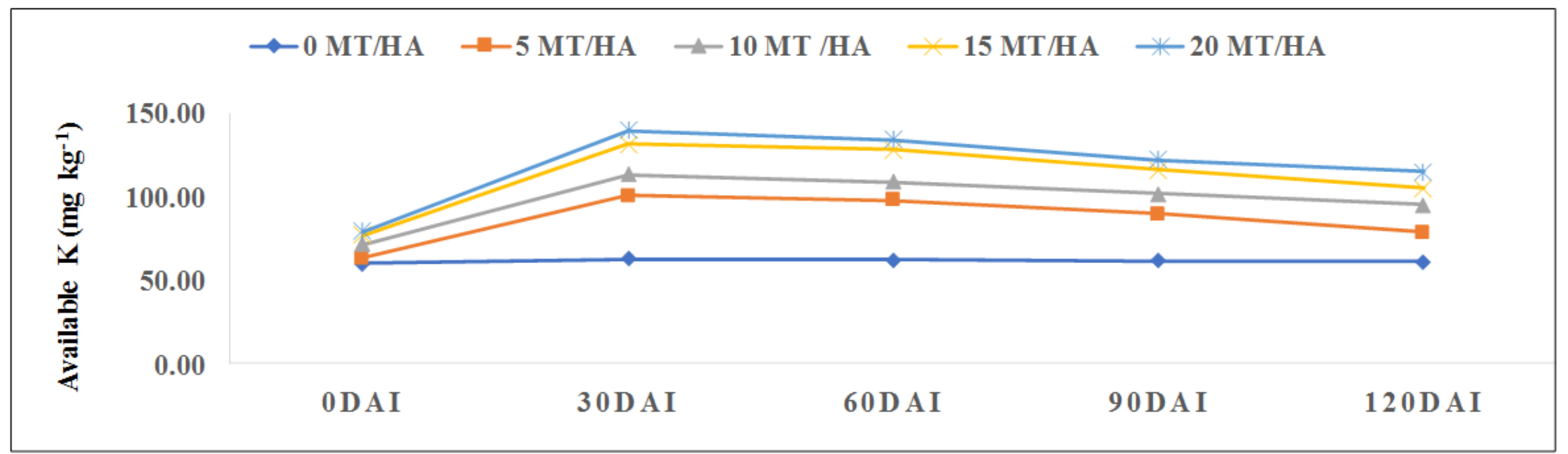

Fig.4 Effect of graded doses of pressmud compost on available potassium content during incubation at different days

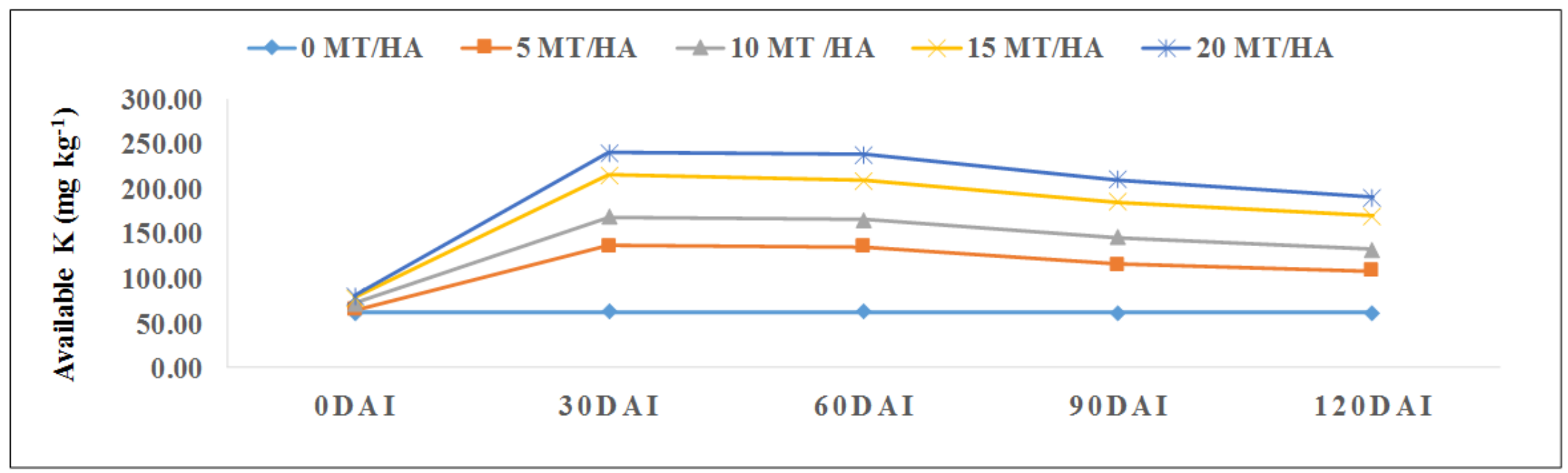




\section{Available potassium}

The results obtained with respect to the content of available $\mathrm{K}$ in soil treated with different levels and sources of organics have been presented in Figure 3 and 4. Available potassium constitutes water soluble and exchangeable potassium. Thus the factor that changes water soluble and exchangeable $\mathrm{K}$, too have effect on available $\mathrm{K}$ status of soil. Result shows that the release of potassium was lower in soil receiving no potassium in comparison to treatment receiving farmyard manure and pressmud compost. There was increase in available potassium from 0 to 30 days after incubation (DAI), whereas, a decrease up to 120 days of incubation. Results suggest that inclusion of organic material maintains considerable amount of available $\mathrm{K}$ for longer period of time and depletes at slower rate. The maximum release of $\mathrm{K}$ occurred at 30 DAI in the treatment $\mathrm{T}_{4}(20$ MT $\mathrm{ha}^{-1}$ applied organics), while, in case of farmyard manure, $\mathrm{T}_{4}$ was at par with the treatment $\mathrm{T}_{3}$ (15 MT ha ${ }^{-1}$ organics). Farmyard manure treated plot showed $122 \%$ increase in potassium over control whereas in case of pressmud compost treated plot the increase was to the extent of $282 \%$ over control. The rate of decrease was very slow in case of farmyard manure treated plot and was only $3.8 \%$ from 30 to 60 DAI whereas in case of pressmud compost treated plot it was $0.84 \%$. Farmyard manure and pressmud compost is not only a source of $\mathrm{K}$ availability but also increases CEC of soil by increasing organic surface capable of ion exchange, resulting in an increase in exchangeable and plant available K (Blake et al., 1999). Lal et al., (2000) reported that with the increase in incubation time the $\mathrm{K}$ mineralized increased significantly and raised the available $\mathrm{K}$ pool in soil due to release of more organically bound potassium in course of decomposition of organic waste (Bear, 1976). Dhanorkar et al., (1994) observed that increase in available
$\mathrm{K}$ was not only due to enrichment of $\mathrm{K}$ by organic source but native $\mathrm{K}$ also become more available due to action of organic acids liberated during decomposition of organic matter. Brar et al., (2008) also reported increased availability of $\mathrm{K}$ content in manured soil than unmanured soil. The result obtained on availability of $\mathrm{K}$ under incubation study was similar to findings of Kaur and Benipal (2006).

Results of incubation study indicated that the organic sources either farmyard manure or pressmud compost ensures consistent availability of nutrients throughout the growth period by augmenting microbial growth, releasing organic acids and by forming chelates with essential plant nutrients and prevent their fixation which favors availability of nutrient to crop.

\section{References}

Bear, P. E., (1976). Chemistry of soil. Pp 280. Second Edn Oxford and IBH publishing Co. New Delhi.

Blake, L., Goulding, K.W.T., Mott, C.J.B. and Johnston, A.E. (1999). Changes in soil chemistry accompanying acidification over more than 100 years under woodland and grass at Rothamsted Experimental Station, UK. European Journal of Soil Science. 50: 401-12.

Brar, M.S., Mukhopadhyay, S.S., Dhillon, N.S., Sharma P. and Singh, A. (2008). Potassium: Mineralogy and status in soils, and crop response in Punjab, India. International Potash Institute, Horgan, Switzerland, p. 69.

Dhanorkar, B.A., Borkar, D.K., Puranik, R.B. and Joshi R.P. (1994). Forms of soil potassium as influenced by long-term application of FYM and NPK in vertisol. Journal of Potassium Research. 10: 42-48.

Duffera, M., Robarge, W. P. and Mikkelsen, R. L. (1999). Estimating the availability of nutrients from processed swine lagoon solids through incubation studies. Bioresource technology. 70(3): 261-268. 
Hanway, J. J. and Heidel, H., (1952). Soil analysis methods as used in Iowa State College, Soil Testing Laboratory, Iowa State College Bulletin. 57: 1-131.

Jackson, M. L. (1973). Soil Chemical Analysis. Prentice Hall, New Delhi.

Kaur, N., and Benipal, D.S. (2006). Effect of crop residue and farmyard manure on $\mathrm{k}$ forms on soil of long term fertility experiment. Indian Journal Crop Science. 1(1-2): 161-164.

Keen, B. A., and Raczkowski, H. (1921). The relation between the clay content and certain physical properties of a soil. The Journal of Agricultural Science, 11(4), 441-449.

Keeney, D. R., and Nelson, D. W. (1982). Nitrogen in organic forms. Pages 643-698 in A. L. Page et al., Eds. Methods of soil analysis. Part 2. Agronomy No. 9, American Society of Agronomy, Madison, WI.

Kolahchi, Z., and Jalali, M. (2012). Kinetics of nutrient release from different organic residues using a laboratory system, Archives of Agronomy and Soil Science. 58 (9):10131031.

Kumar, S., Srivastava, A., \& Gupta, A. (2015). Effect of organic amendments on availability of different chemical fractions of phosphorus. Agricultural Science Digest-A Research Journal. 35(2): 83-88.

Lal, J. K., Mishra, B. and Sarkar, A. K. 2000. Effect of Plant Residues incorporation on specific microbial groups and availability of some plant nutrients in soil. Journal of the Indian Society of Soil Science, 48:67-71.

Mohanty, M., Probert, M. E., Reddy, K.S., Dalal, R.C., Rao, A.S. and Menzies, N.W. (2010) Modelling $\mathrm{N}$ mineralization from green manure and farmyard manure from a laboratory incubation study 19th World Congress of Soil Science, Soil Solutions for a
Changing World 24, 1-6 August 2010, Brisbane, Australia.

Moorhead, D. L., Sinsabaugh, R. L., Linkins, A. E., Reynolds, J. F. (1996). Decomposition processes: modeling approaches and applications. Science of the Total Environment. 183, 137-149.

Olsen, S. R., Cole, C. V. Watanabe, F. S. and Dean. L. A. (1954). Estimation of Available Phosphorus in Soils by Extraction with Sodium Bicarbonate. U. S. Department of Agriculture Circular No. 939.

Panse, V.G. and Sukhatme, P.V. (1967) Statistical methods for Agricultural Workers. ICAR, New Delhi, pp. 97-123.

Singh, N. J. and Patel, K.P. (2016) Influence of Plant Nutrient (Organic and Inorganic) on Nutrient Dynamics in the Soils of Golagamdi, Vadodara District, Gujarat. Environment and Ecology. 34(4c):24142419.

Subbiah, B. and Asija. G. L. (1956). A rapid procedure for estimation of available nitrogen in soils. Current Science 25. 259-260.

Tian, G., Brussard, L., Kang, B. T. (1995): An index for assessing the quality of plant residues and evaluating their effects on soil and crop in the (sub) humid tropics. Applied Soil Ecology. 2, 25-32.

Tian, G., Kang, B. T., Brussard, L. (1992): Biological effects of plant residues with contrasting chemical composition under tropical conditions - decomposition and nutrient release. Soil Biology and Biochemistry. 24, 1051-1062.

Villegas-Pangga, G., Blair, G. and Lefroy, R. (2000). Measurement of decomposition and associated nutrient release from straw (Oryza sativa L.) of different rice varieties using a perfusion system. Plant and Soil. 223(1): 111.

\section{How to cite this article:}

Bipin Bihari, Ragini Kumari and Shweta Shambhavi. 2018. Release Pattern of Inorganic N, Phosphorus and Potassium as Influenced by Farmyard Manure and Pressmud Compost under Laboratory Incubation Study. Int.J.Curr.Microbiol.App.Sci. 7(09): 2476-2483.

doi: https://doi.org/10.20546/ijcmas.2018.709.307 